University, the Institute celebrated its 10th Anniversary this summer. Funding in previous years has come from the participating institutions, especially Emory University and the University of Virginia, the Ford Foundation, the Coca-Cola Foundation, the U.S. Department of Education, the William S. Paley Foundation, and the members of APSA.

\section{Former Ralph Bunche Student, Now an Inspiration to Students}

\footnotetext{
"I recently took a moment to assess my accomplishments as well as the key individuals and organizations which have contributed to them," writes Thomas Stewart. A Harvard Ph.D. in political science, member of Harvard's Society of Fellows, and former president of the National Black Graduate Student Association, Thomas Stewart sees the roots of his later successes largely in the Ralph Bunche Summer Institute in which he participated in 1986. "My career Stewart testifies to the fact that programs like the Ralph Bunche Institute accomplish this important work. "The Institute raised my awareness of the opportunities which exist within political science. It prepared me for the rigors of graduate school, and it exposed me to representatives from some of the salient political science programs across the country."

"Without the Institute," he adds, "I can safely say I would not be where I am today."
} would have taken a dramatically different course were it not for the Ralph Bunche Summer Institute."

Indeed, Stewart's successes represent a sharp contrast with his youth when he barely graduated from his Washington, D.C. high school and later failed out of the University of the District of Columbia in 1980. What's most surprising is that Stewart is a newly-hired professor in the Department of Criminology at the very university from which he dropped out.

Stewart says that the Ralph Bunche Summer Institute along with his 1980-83 Army stint taught him he could make serious contributions to society. "I came to understand that everyone has enough intellect to meet high standards," Stewart recently said in an interview with The Washington Post. "I realized that I had internalized a myth that people on my side of the color line just didn't have what it takes. My greatest challenge was rooting out that sense of inferiority from my mind and heart."

Now Stewart seeks to impart that same knowledge to his students, most of whom come from Washington, D.C. "The blessing of growing up in D.C. is that this is where the people are who like me and love me most," Stewart said. "But the curse is that we are also our own worst critics. A lot of derogatory things I learned about black people came from black people, the most destructive being the suggestion that we can run, jump, dance, and sing, but when it comes to intellectual pursuits, that's a different ball game."

Combating the defeatist attitude toward intellectual engagement, Stewart says, is among the most important tasks to be accomplished in African-American communities. And

\section{APSA Announces 1997-98 Minority Student Graduate Fellows}

APSA announced in December the names of the fourteen 1997-98 Minority Graduate Fellows. This year's Fellows hail from some of the best undergraduate institutions in the United States and took part in a highly competitive fellowship selection process. Five funded Fellows include Louis Toman of the University of California, Berkeley; Christina Calderon, Pepperdine University; Eleanor Mack, Xavier University of New Orleans; Kellye Campbell, University of Southern California; and Llezlie Green of Dartmouth College.

Non-funded Fellows are recommended for admission to every doctoral political science program in the country and often receive funding from universities as a result of their status as Fellows. This year's nonfunded Fellows include Rodolfo Espino, III of Luther College; Antonio Vazguez-Arroyo, University of $\mathrm{Pu}-$ erto Rico; Liban Jama of the University of Michigan; Jay Bonds of Duke University; Dawn Simms, St.
Mary's University; Shelby Smith, Duke University; Jowanna Oates, Florida A\&M University; Eyvon Curry, University of South Florida; and Erin Rachelle Brown of Loyola University in New Orleans.

APSA Minority Fellowships were established to increase the number of minorities with doctoral degrees in political science. Fellowships are open to outstanding Native Americans, Latino(a)s, and African Americans planning to enroll in a doctoral program in the coming academic year. Each year the application deadline falls on November 1. For more information, call or write APSA headquarters or visit the APSA website at http://www.apsanet.org

\section{CFP Orientation Shows Fellows Washington from the Inside}

APSA's Congressional Fellowship Program initiated 1996-97 Fellows "inside the beltway" with a threeweek orientation in November. Beginning with $\mathrm{Al}$ Hunt of the Wall Street Journal and TV's The Capitol Gang, and ending with Secretary Donna Shalala of the Department of Health and Human Services, the orientation roster included some of Washington's leading commentators and scholars.

Thirty-five Congressional Fellows met with retired Senator Paul Simon (D-IL) and Representative David Price (D-NC), a CFP Advisory Committee member returned to Congress after being narrowly defeated in the 1994 election. C-SPAN founder and CEO Brian Lamb, David Broder and Barbara Vobejda both of The Washington Post, and Congressional Quarterly political editor and author Ronald Elving also met with the Fellowship class, as did lobbyist Gary Hymel, Democratic pollster Celinda Lake, Martha Phillips, executive director of The Concord Coalition, and Stephan Richter, president of Transatlantic Futures.

Additionally, Norman Ornstein, chair of the CFP Advisory Committee, spoke to the group as did scholars Thomas E. Mann, Roger Davidson, Christopher Deering, Allen Schick, Richard Baker, Susan Hammond, Clyde Wilcox, Suzanne Garment, Catherine Rudder and James 
Pfiffner. Fellows were also introduced to the Congressional Research Service through its two-day orientation program.

Each year, political scientists, journalists, international scholars, health policy scholars, and Federal executives are selected to become Congressional Fellows under a highlycompetitive review process. Once

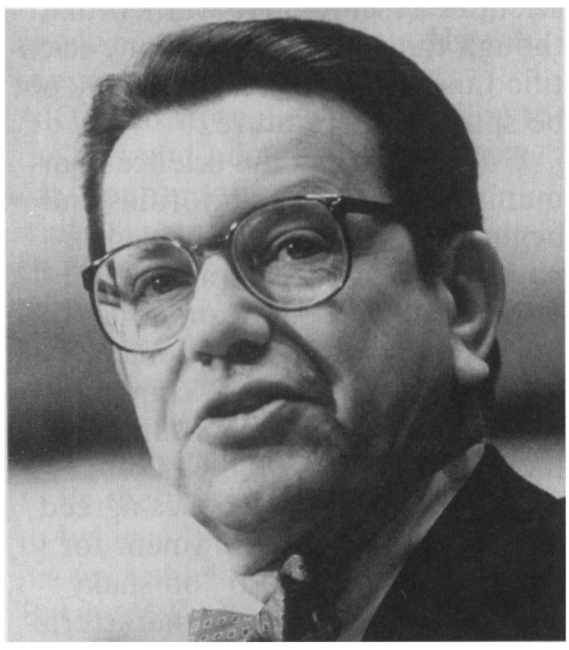

Paul Simon orientation is completed in December, Fellows are expected to secure positions in congressional offices where they work until August, often changing sides mid-way through the program to become acquainted with both House and Senate procedures.

Information on the Congressional Fellowship Program can be obtained by calling APSA or by visiting the APSA's website: http://www. apsanet.org.

\section{Paul Simon Retires to Southern Illinois University}

In 1951, at the age of 22, Paul Simon was summoned to Washington to testify before the Senate Crime Investigating Committee. As editorpublisher of the Troy Tribune, Simon helped expose a gambling syndicate in Madison County, Illinois, and the Committee wanted to investigate his findings. That was the first time the Senate called upon Simon's expertise.

After 12 years of lending his expertise as a Senator, which were pre- ceded by 10 years in the House of Representatives, the now-retired Senator and elder statesman has no plans of acting elderly and certainly no plans of retiring.

As director of the newly-formed Paul Simon Public Policy Institute at Southern Illinois University, Simon plans to focus his attention on an array of social and political issues. Speaking to APSA Congressional Fellows in December, Simon said his future remains open, though he does plan to join heads with former President Jimmy Carter to address domestic poverty issues and American relations in Africa.

In addition to organizing church leaders in a crusade against poverty and furthering public discussion on health care and international relations, Simon plans to teach courses each semester at Southern Illinois. This spring, the former member of the Congressional Fellowship Program Advisory Board teaches a lecture course on the legislative process and a seminar on non-fiction writing; as an eminent legislator and author

\section{Contributors to APSA Awards and Programs}

Kristi Anderson
Lavonna J. Blair
Gildo Marcal Brandao
Allan R. Brown
Charles S. Bullock III
James E. Campbell
Michael P. Canning
Elliot W. Carlson
Pamela J. Conover
Timothy E. Cook
Robert L Goerder
Esther S. Goldstein
Woodford Howard, Jr.
Lyn Kathlene
Francis J. Keenan

Kristi Anderson

Lavonna . Blair

Allan R. Brown

Charles S. Bullock III

James E. Campbell

Michael P. Canning

Elliot W. Carlson

Pamela J. Conover

Timothy E. Cook

Robert L Goerder

Esther S. Goldstein

Lyn Kathlene
Francis J. Keenan

\author{
Gilbert M. Khadiagala \\ John F. Kozeletz \\ Alice M. Litwinowicz \\ $\operatorname{Logan} A$. Lee \\ Donald J. Matthewson \\ Nancy R. McWilliams \\ William L. Oakley \\ Jack W. Peltason \\ Lucian W. Pye \\ Wilbur C. Rich \\ Leroy N. Rieselbach \\ Molly Lyndon Shanley \\ Theda Skocpol \\ Gary D. Smith \\ John D. Sprague
}

\author{
R.V. Steffel \\ Donald E. Stokes \\ David Swickard \\ Joan Hulse Thompson \\ Barbara A. Vobejda \\ Hanes Walton, Jr. \\ Kenneth Waltz \\ Richard D. Warden \\ Jennifer Widner \\ John E. Yang \\ Thank you!
}

